\title{
Learning Ecosystems with Educational Monopoly Media
}

\section{Ni Putu Martika Kusumayanti ${ }^{*}$, Gede Wira Bayu ${ }^{2}$}

1,2 Program Studi Penddikan Guru Sekolah Dasar, Universitas Pendidikan Ganesha, Singaraja, Indonesia

\section{ART I CLE INFO}

Article history:

Received March 03, 2021

Revised March 09, 2021

Accepted May 07, 2021

Available online May 25, 2021

Kata Kunci:

Media, Monopoli Edukatif Ekosistem

Keywords:

Media, Educational Monopoly, Ecosystem

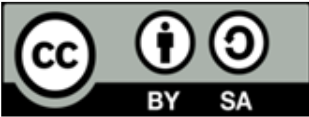

This is an open access article under the CC BY-SA license.

Copyright (C) 2021 by Author. Published by Universitas Pendidikan Ganesha.

\begin{abstract}
A B S T R A K
Kurangnya ketersediaan media pembelajaran pada topik ekosistem yang mengakibatkan proses pembelajaran kurang efektif. Penelitian ini bertujuan untuk mendeskripsikan prototype pengembangan media pembelajaran monopoli edukatif dan menghasilkan media pembelajaran monopoli edukatif yang teruji validitasnya. Jenis penelitian ini yaitu penelitian pengembangan dengan menggunakan model ADDIE yang terdiri dari lima tahapan yaitu analyze (analisis), design (desain), development (pengembangan), implementation (implementasi), dan evaluation (evaluasi). Subjek uji coba dalam penelitian ini terdiri dari 2 orang ahli materi, 2 orang ahli media dan desain, 2 orang praktisi, 3 orang siswa untuk uji coba perorangan dan 6 orang siswa untuk uji coba kelompok kecil. Metode pengumpulan data penelitian ini menggunakan metode kuesioner dengan penyebaran instrumen rating scale berskala 4. Data hasil penilaian yang diperoleh dianalisis dengan rumus Mean untuk mendapatkan rata-rata skor. Rata-rata skor dari ahli materi, ahli media, ahli desain, praktisi, uji coba perorangan, dan uji coba kelompok kecil secara berturut-turut yaitu sebesar 3,79; 3,86; 3,78; 3,70; 3,80 dengan kualifikasi sangat baik/layak. Sehingga secara keseluruhan validitas media pembelajaran monopoli edukatif berada pada rentangan $3,25<x<4,00$ dengan kualifikasi sangat baik. Berdasarkan analisis tersebut media pembelajaran monopoli edukatif pada muatan IPA topik ekosistem layak untuk digunakan dalam pembelajaran
\end{abstract}

\begin{abstract}
A B S T RA C T
Lack of availability of learning media on ecosystem topics which results in the learning process being less effective. This study aims to describe the prototype of the development of educational monopoly learning media and to produce educational monopoly learning media whose validity has been tested. This type of research is a development research using the ADDIE model which consists of five stages, namely analyze, design, development, implementation, and evaluation. The trial subjects in this study consisted of 2 material experts, 2 media and design experts, 2 practitioners, 3 students for individual trials and 6 students for small group trials. This research data collection method using a questionnaire method with the distribution of a 4 scale rating scale instrument. The data obtained from the assessment results were analyzed using the Mean formula to obtain an average score. The average score of material experts, media experts, design experts, practitioners, individual trials, and small group trials respectively was 3,79, $3,86,3,78,3,70,3,80$ with very good qualifications. So that the overall validity of the educational monopoly learning media is in the range of $3.25<\mathrm{x}<4.00$ with very good qualifications. Based on this analysis, the educational monopoly learning media on the science content of the ecosystem topic is suitable for use in learning.
\end{abstract}

\section{INTRODUCTION}

Natural Sciences is one of the subjects taught in elementary schools, which studies about nature (Junge et al., 2021). Natural science is an activity carried out systematically to gather information and learn about nature (Septiani \& Astawan, 2020). The content of natural science learning discusses nature and its contents. In the learning process the use of learning media is very necessary to make it easier to convey learning material. The use of media in learning activities is expected to be able to form a stimulus to support the achievement of learning objectives (Rasvani \& Wulandari, 2021). Learning media are made according to the characteristics of students. Elementary school students prefer it when learning is done while playing. Learning media with the concept of a game can increase enthusiasm and can motivate students to learn (Andreani \& Ying, 2019; McFeetors \& Palfy, 2018). Good learning media must meet at least three requirements. The first is educational requirements, namely the suitability of learning media with learning objectives. Second, manufacturing techniques include quality learning media forms and materials. Third, the beauty that includes learning media must have an aesthetic form and attractive colors (Asyhari \& Silvia, 2016). Natural science learning is said to be successful if students are able to understand the material being taught well (Sakiyah \& Sunarti, 2020; Trianawati et al., 2020). In science 
learning, the teacher should be a facilitator for the creation of active, creative, innovative and fun learning, thus the use of media in learning is indispensable.

But in fact, based on observations in class VB SD Negeri 2 Kalibukbuk, the availability of instructional media is still lacking, in schools there are only image media such as pictures of flower parts, the digestive system, the respiratory system and maps. Lack of learning media has an impact on students' lack of interest in learning. According to the class VB teacher of SD Negeri 2 Kalibukbuk, the students' science scores tend to be low due to the lack of willingness of students to learn. Students are bored with monotonous learning that only uses the lecture method. Students prefer to play than learn, when participating in learning, students are less focused in responding to problems given by the teacher so that often the answers given by students are not connected with the questions given by the teacher. In addition, students also do not understand the material being studied, students are only able to absorb the material being taught about $60 \%$ of the overall material because students pay less attention and are lazy to read the material in the learning process. Similar problems were also found in previous studies, namely students felt bored with monotone learning (Andreani \& Ying, 2019). If improvements are not made, it will have an impact on the learning process that is less effective and students are less motivated to learn. So that the competence of students' knowledge is low.

Innovation in the learning process is very important in order to overcome student boredom and can improve students' thinking skills (Huang et al., 2020; Ruipérez-Valiente \& Kim, 2020). Presentation of creative and interesting material is able to have a positive influence on students (Mahesti \& Koeswanti, 2021). Alternative solutions that can be taken to overcome these problems are by developing educational monopoly learning media. This is in line with several previous studies. Based on these results it can be seen that the Monopoly learning media is suitable for use in the learning (Fitriani et al., 2019; Nurfitriana \& Nugraha, 2019; Peranti et al., 2019; Pradana, 2018; Prayogo et al., 2017). Based on several previous studies, the educational monopoly learning media was declared feasible. Educational monopoly learning media has an attractive appearance, with complete components so that it can motivate students to learn. The weakness of the educational monopoly learning media is that it takes a long time to play this media because before starting the game you have to share the game money first and it also takes a long time to calculate the amount of wealth each player has.

The development of monopoly learning media is important to do so that learning is more effective and can achieve the expected learning objectives. The novelty of educational monopoly learning media is made with a relatively large size, namely $80 \mathrm{~cm} \times 80 \mathrm{~cm}$, made using patent materials, and educational monopoly instructional media designs made with attractive and bright pictures. The advantages of educational monopoly learning media are that it can increase student enthusiasm for learning because students feel fun when learning in class, educational monopoly learning media can overcome student boredom because learning is monopoly, can increase student interest in learning and is made in a colorful manner so that it can attract student attention. This study aims to produce a prototype of educational monopoly learning media and to produce educational monopoly learning media that has proven its validity. The implementation of this development is the creation of educational monopoly learning media prototypes and the creation of educational monopoly learning media that are suitable for use in the learning process.

\section{METHOD}

The type of research used in this research is research and development. The development research model used in the research on the development of educational monopoly learning media is the ADDIE model. ADDIE model is a learning development model and development procedure (Suryani et al., 2018). The ADDIE model is a development research model consisting of five stages, namely Analyze, Design, Develop, Implementation, and Evaluation. At the Analyze (analysis) stage, a needs analysis was carried out by conducting observations and interviews with the homeroom teacher of class V SD 2 Kalibukbuk to find out the problems experienced in the learning process, curriculum analysis was carried out by analyzing teacher books, KD student books and indicators, student characteristic analysis was carried out by observing students and media analysis was carried out in order to obtain information regarding the availability of media at SD N 2 Kalibukbuk. At the design stage, a prototype (design) of the product to be developed is carried out. At the develop stage, the product is made, starting from the preparation of the initial product, testing the validity of the product, revising the product and then producing the final product. In the implementation stage, the product is applied in the classroom learning process. And in the evaluation stage, an assessment of the learning process that has used educational monopoly learning media is carried out. However, due to the pandemic situation and conditions, the implementation and evaluation stages cannot be carried out. 
The validity test of educational monopoly learning media was carried out by 2 material experts, 2 media experts, 2 design experts, 2 practitioners and 9 students for individual and small group trials. In this study, using a questionnaire method to collect reviews from experts. The questionnaire method is a method that is carried out by giving a number of questions or written statements to get answers from respondents (Agung, 2014). The validity test of the Educational Monopoly learning media was carried out using the Rating scale instrument. The validity test instrument in the development of educational monopoly learning media consists of instruments of material experts, media experts, design experts, practitioners, and individual and small group trials. The making of the instrument begins with making a lattice table, the aspects of the validity test of the media on the instrument consist of material aspects, linguistic aspects, presentation aspects, display aspects, illustration design suitability aspects, and usage aspects that are described for the assessment of material experts, experts. media, design experts and individual and small group trials. Meanwhile, the practitioner's assessment uses a combination of the aspects of the assessment of material experts, media experts, and design experts.

Then the instrument that has been made is tested jugdes to determine the content validity and reliability of the instrument. The content validity test in this study used the Gregory formula. The data obtained were then converted into a $2 \times 2$ cross tabulation table. The results of the content validity test of the material expert assessment instrument, media expert, design expert, practitioner and individual and small group trials were $0.86,1.00,1.00,0.91$, and 0.87 respectively with validity criteria. content is very feasible to be used in measuring the validity of educational monopoly learning media. In this study, a reliability test was conducted to determine the accuracy of the instruments made. The formula used to measure the reliability of the instruments in this study was the percentage of agreements from the two assessors. After calculating the reliability of the instruments made, the reliability value is obtained. For decision making, the reliability criteria developed by Guilford are presented in Table 1.

Table 1. Instrument Reliability Criteria

\begin{tabular}{lll}
\hline \multicolumn{1}{c}{ Limitation of Reliability Coefficient } & & Criteria \\
\hline $0 \%<\mathrm{r} \leq 20 \%$ & Very Low & \\
$20 \%<\mathrm{r} \leq 40 \%$ & Low & \\
$40 \%<\mathrm{r} \leq 60 \%$ & Moderate & \\
$60 \%<\mathrm{r} \leq 80 \%$ & High & \\
$80 \%<\mathrm{r} \leq 100 \%$ & Very High \\
\hline
\end{tabular}

(Candiasa, 2011)

The data analysis technique used in this research is descriptive quantitative and qualitative analysis techniques. Qualitative descriptive analysis is carried out by processing qualitative data in the form of suggestions from experts to improve Educational Monopoly learning media. Quantitative descriptive analysis is carried out by finding the average of the scores given by the experts. Then the average obtained is converted into a scale of 5. For decision making, it can be given meaning to the results obtained as shown in Table 2.

Table 2. Five Scale Assessment

\begin{tabular}{lcc}
\hline & Score Range & Predicate Classification \\
\hline $3,25<\mathrm{X} \leq 4,00$ & Very good \\
$2,75<\mathrm{X} \leq 3,25$ & Good \\
$2,25<\mathrm{X} \leq 2,75$ & Pretty good \\
$1,75<\mathrm{X} \leq 2,25$ & Bad \\
$1,00<\mathrm{X} \leq 1,75$ & Very bad \\
\hline
\end{tabular}

(Koyan, 2012).

\section{RESULT AND DISCUSSION}

Result

Analyze stage, at this stage, needs analysis, curriculum analysis, student characteristic analysis and learning media analysis are carried out. The analysis stage was carried out by interviewing the homeroom teacher of class V SD Negeri 2 Kalibukbuk and conducting an observation. The results of interviews with class $\mathrm{V}$ teachers showed that the percentage of student learning outcomes tended to be low, reaching only $30.76 \%$. The low percentage of student completeness was caused by a lack of students' 
willingness to learn, students preferred playing compared to learning. The low enthusiasm of students in taking part in learning, this happens because students tend to be bored with monotonous learning. Meanwhile, based on observations in grade V SD Negeri 2 Kalibukbuk, it is known that the availability of media is still lacking, the available media is only limited to image media. Lack of teacher creativity in developing instructional media in accordance with student characteristics. The scope of material in student books, especially on ecosystem material, is still very limited, so additional material is needed so that it is in accordance with the KD and the expected indicators.

The design stage, at the design stage, a prototype (design) for the development of educational monopoly learning media is carried out. The design of the media was made using the Photoshop CS6 application. At this stage the researchers made a monopoly educational media design consisting of a game board design, a game card design, and a game money design. Making a media design begins with the creation of a game board design consisting of game plots. Game cards consist of chance cards, question cards, smart cards, and tile ownership cards. The design of the educational monopoly game money is also a modified result of the monopoly game money in which pictures are added related to the topic of the ecosystem. The final products at this stage are game board designs, smart cards, quiz cards, tile ownership cards and game money.

The development stage, begins with the preparation of the initial product and then printed. The game board is made with $80 \mathrm{~cm}$ x $80 \mathrm{~cm}$ plywood. Game cards are made with buffalo paper and laminated, game pieces use miniature animals, houses are made of wood, and game dice are made of plastic with a size of $3 \mathrm{~cm} \times 3 \mathrm{~cm}$. Then the product validity test is conducted to determine the feasibility of the product being made. Product validation is carried out by four experts in their fields consisting of two material experts and two media experts as well as design experts and two practitioners. Product trials also involve nine students consisting of three people to do individual trials and six people to do small group trials. The results of product trials are in the form of qualitative data and quantitative data. Qualitative data in the form of feedback and suggestions from the assessors are used as material for revising educational monopoly learning media. Feedback and suggestions from the assessors are presented in Table 3.

Table 3. Feedback, Suggestions and Comments

\begin{tabular}{cll}
\hline No & \multicolumn{1}{c}{ Assessor } & \multicolumn{1}{c}{ Feedback, Suggestions and Comments } \\
\hline 1. & $\begin{array}{l}\text { Material/Content } \\
\text { Expert }\end{array}$ & $\begin{array}{l}\text { The questions on the quiz cards are made or arranged with a higher order } \\
\text { thinking skills (HOTS). }\end{array}$ \\
2. $\begin{array}{l}\text { Learning } \\
\text { Expert }\end{array}$ & $\begin{array}{l}\text { Add color variants to the house as many as } 6 \text { colors. } \\
\text { Add rubber to the educational monopoly instructional media board elbow. } \\
\text { Laminate the game money. } \\
\text { Fix the font on the quiz card. } \\
\text { Adjust the concept of the game rules. }\end{array}$ \\
\hline
\end{tabular}

At the development stage, the product is first revised according to input and suggestions from material experts. Based on the evaluation of material experts, the product is declared good, it just needs a little improvement. The quiz card needs to be revised into HOTS questions, and the letter size on the card should be enlarged. At the development stage, the two educational monopoly learning media were assessed by Media Experts, Design Experts and Practitioners. The results of the assessment from Media Experts, Design Experts and Practitioners stated that the monopoly educative learning media was good, but still needed to be improved. Inputs and suggestions from media experts are to add color variants to the media houses, add rubber to the media bracket and melamine the game money. Input and advice from design experts is to improve the font on the quiz card and improve the game concept. At the development stage, the three products were assessed by students in individual trials and small group trials. The results of small group trials and individual product trials were declared feasible and students did not provide input, suggestions or comments for product improvement.

Analyze stage is carried out needs analysis, curriculum analysis, student characteristic analysis, and media analysis. The results of the needs analysis show that it is necessary to develop instructional media in class V SD Negeri 2 Kalibukbuk. The results of the curriculum analysis are to determine the basic competencies and indicators of achievement on the topic of ecosystems. The results of the analysis of student characteristics were found that the fifth grade students of SD Negeri 2 Kalibukbuk need learning media with the concept of playing because students tend to prefer to play compared to learning. The results of media analysis show that good learning media must be attractive and in accordance with student characteristics. 
In the design stage, the design of monopoly educational learning media is carried out. At the design stage, a prototype (design) of educational monopoly learning media was made, consisting of game board designs, quiz cards, smart cards, ownership cards, game money and user manuals. The design of educational monopoly learning media begins with designing a monopoly game board consisting of game plots, then proceed with making a plot ownership card design, quiz card, smart card, game money and designing a manual for using the media. The design of the educational monopoly learning media was made using the Adobe Photoshop CS6 application. After the design of the educational monopoly learning media is complete, guidance is carried out with the supervisor to get input and suggestions so that it can proceed to the printing stage. At the design stage, an assessment instrument is compiled consisting of assessment instruments from material experts, media experts, design experts, practitioners, individual and small group trials, then the instruments are assessed by experts to determine the validity and reliability of the instruments made.

The development stage carried out the development of educational monopoly learning media in accordance with the design made. The designs are developed with interesting ecosystem images. In addition, the educational monopoly learning media is printed in a larger size, namely $80 \mathrm{x} 80 \mathrm{~cm}$. The monopoly game board is made to resemble a foldable chessboard using plywood and wood. The image on the game board is printed using a banner then affixed to the top of the board made of plywood. To make it stronger, glass is added to the top of the game board. In addition to board games, game cards are developed according to the topic of the ecosystem. on the quiz card there are questions related to the topic of ecosystems. on the smart card there is material related to the topic of the ecosystem. The game pieces are also modified into animal miniatures to make them more interesting and in accordance with the ecosystem topic. The media is also equipped with a user manual so that students can understand how to use the media. After completing the development of the media, then a media review was carried out by 4 experts consisting of 2 material experts, 2 media experts as well as design experts, and 2 teachers as practitioners. The review is carried out to obtain an assessment in the form of a score as well as input, suggestions and comments for the improvement of educational monopoly learning media.

The results of the validity test of educational monopoly learning media were declared feasible with the response of material experts obtaining an average score of 3.79, media experts by 3.86, design experts of 3.78, practitioners giving an average score of 3.84. Educational monopoly learning media also received a response from students, in individual trials the average score of the three students was 3.70 and in small group trials with six students, obtaining an average score of 3.80. So that the overall validity of the educational monopoly learning media is in the range of $3.25<x<4.00$ with very good qualifications and is suitable for use in the learning process.

\section{Discussion}

Educational monopoly learning media is declared feasible because the presentation of the material is in accordance with KD and indicators. Selection of material and presentation of material is important in making learning media to suit the characteristics of students so that students can understand the material well (Chayani \& Rachmadyanti, 2020). Judging from the language used, monopoly learning media uses language that is easily understood by students and the material is well presented, this can be seen from the suitability between images and information on the media. In making learning media, you must pay attention to the use of language so that it is easier for elementary school students to understand (Nurjanah \& Sumarmi, 2020). The overall appearance of the media looks attractive, the media design is good, physically the media prints are neat, and the materials used are strong and durable and the media usage manual is clear. Learning media must have an attractive appearance, because with an attractive appearance the media can motivate users (Putra \& Putra, 2021; Utami \& Abdulah, 2020). Educational monopoly learning media design is good with bright colors and clear pictures. The choice of color in making learning media can have a psychological effect on its users spontaneously (Sentarik \& Kusmariyatni, 2020). Through the visualization of images on educational monopoly learning media, it can be used as a link between material and real life (Viana Sari \& Kusmariyatni, 2020). Based on Piaget's theory of cognitive development, it is stated that grade V SD children are at the concrete operational stage. Children who are at the concrete operational stage generally understand the material with the help of concrete objects or pictures, children have difficulty doing tasks that require logic for completion (Halford, 2017; Juwantara, 2019).

The results of this study are in line with the research who get the results that monopoly learning media is suitable for use in the learning process (Fitriani et al., 2019). These results were obtained based on the results of the validity test of the three experts who showed that the criteria were feasible with an average percentage of $87 \%$. Another suitable research is research who get the results that monopoly learning media is suitable for use in the learning process with an assessment from material experts 
obtained that is $92.64 \%$ and an assessment from media experts is $91.66 \%$ so that monopoly learning media is declared valid and suitable for use in the learning process (Prayogo et al., 2017). Research conducted with content expert review results of $92 \%$, design expert review results of $93 \%$, media expert review results of $95 \%$, individual trial results of $94.6 \%$, small group trial results of $93.5 \%$, and trial results. field of $91.5 \%$ so that the educational monopoly learning media was declared fit for use in the learning process (Khasanah et al., 2018). Other research obtained an assessment from material experts by $90 \%$, obtained an assessment from media experts by $82 \%$, and obtained an assessment on a limited test of $88 \%$ so that monopoly learning media was declared fit for use in the learning process (Nurfitriana \& Nugraha, 2019). Based on previous research conducted, it is believed that the educational monopoly learning media is feasible to be used in the learning process.

The use of media in learning is very necessary to be able to help students understand the material. Monopoly learning media is an interesting medium and with the use of this media students will certainly use their sensory tools more so that in the end they can achieve the learning objectives as expected. The use of educational monopoly learning media in the learning process is in line with constructivism theory which focuses on direct experience acquisition to build knowledge (Karisma et al., 2020). The advantages of monopoly learning media are; 1) can train student cooperation, 2) can increase student interest in learning, 3) can overcome student boredom due to monotunic learning, 3) student activity can be increased, and 4) made in full color so that it can attract students' attention (Ulfa \& Rozalina, 2019).

The implication of this research is that the teacher obtains new knowledge about the making of the prototype of educational monopoly learning media and can find out the validity of the educational monopoly learning media. In the monopoly learning media prototype consists of a game board design, a game card design and a game money design. The design can be added material according to the topic to be taken. In this study, the topic taken was the topic of the ecosystem so that the media developed was educational monopoly learning media on natural science content on the topic of ecosystem. The product is produced in the form of educative monopoly learning media consisting of game boards, quiz cards, plot ownership cards, smart cards, game money, pawns, dice and media usage manuals with the validity of the results stating that the educational monopoly learning media is valid/relevant to be used in the learning process.

\section{CONCLUSION}

The prototype for the development of educational monopoly learning media consists of monopoly game board designs, smart cards, quiz cards, plot ownership cards, game money and also media usage manuals. And the educational monopoly learning media is declared valid / relevant for use in the learning process in the classroom.

\section{REFERENCES}

Agung, A. A. G. (2014). Metodologi Penelitian Pendidikan. Aditya Media Publishing.

Andreani, W., \& Ying, Y. (2019). "PowPow" interactive game in supporting English vocabulary learning for elementary students. International Journal of Elementary Education, 157, 473-478. https://doi.org/10.1016/j.procs.2019.09.005.

Asyhari, A., \& Silvia, H. (2016). Pengembangan Media Pembelajaran Berupa Buletin dalam Bentuk Buku Saku untuk Pembelajran IPA Terpadu. Jurnal Ilmiah Pendidikan Fisika Al-Biruni, 5(1), 1-13. https://doi.org/10.24042/jpifalbiruni.v5i1.100.

Candiasa, I. M. (2011). Pengujian Instrumen Penelitian Disertai Aplikasi ITEMAN dan BIGSTEPS. Undiksha Perss.

Chayani, A. D., \& Rachmadyanti, P. (2020). Pengembangan Media Permainan Jenga Keragaman Budaya Materi Keragaman Suku Bangsa dan Budaya untuk Kelas IV SD. Jurnal Pendidikan Guru Sekolah Dasar, 08, 302-312.

Fitriani, I., Fitriyah, C. Z., \& Hutama, F. S. (2019). Pengembangan Media Pembelajaran "Monopoli Keberagaman" Tema Indahnya Keragaman di Negeriku untuk Peserta Didik Kelas IV. Jurnal Profesi Keguruan, 5(1), 76-82.

Halford, G. S. (2017). Cognitive developmental theories. The Curated Reference Collection in Neuroscience and Biobehavioral Psychology, 1(1), 298-308. https://doi.org/10.1016/B978-0-12-8093245.05787-4.

Huang, S. Y., Kuo, Y. H., \& Chen, H. C. (2020). Applying digital escape rooms infused with science teaching in elementary school: Learning performance, learning motivation, and problem-solving ability. 
Thinking Skills and Creativity, 37(129), 100681. https://doi.org/10.1016/j.tsc.2020.100681.

Junge, K., Schmerse, D., Lankes, E., \& Carstensen, C. H. (2021). Early Childhood Research Quarterly How the home learning environment contributes to children 's early science knowledge - Associations with parental characteristics and science-related activities. Early Childhood Research Quarterly, 56, 294-305. https://doi.org/10.1016/j.ecresq.2021.04.004.

Juwantara, R. A. (2019). Analisis Teori Perkembangan Kognitif Piaget pada Tahap Anak Usia Operasional Konkret 7-12 Tahun dalam Pembelajaran Matematika. Al-Adzka: Jurnal Ilmiah Pendidikan Guru Madrasah Ibtidaiyah, 9(1), 27. https://doi.org/10.18592/aladzkapgmi.v9i1.3011.

Karisma, I. K. E., Margunayasa, I. G., \& Prasasti, P. A. T. (2020). Pengembangan Media Pop-Up Book pada Topik Perkembangbiakan Tumbuhan dan Hewan Kelas VI Sekolah Dasar. Jurnal Ilmiah Sekolah Dasar, 4(2), 121. https://doi.org/10.23887/jisd.v4i2.24458.

Khasanah, I. N., Parmiti, D. P., Gde, I., Sudatha, W., \& Pendidikan, J. T. (2018). Pengembangan Media Monopoli Dengan Model Hannafin Dan Peck Mata Pelajaran Ips Di Sd Mutiara Singaraja. Jurnal Jurusan Teknologi Pendidikan, 9(2), 205-214. https://doi.org/http://dx.doi.org/10.23887/jeu.v6i2.20292.

Koyan, I. W. (2012). Statistik Teknik Analisis Data Kualitatif. Universitas Pendidikan Ganesha.

Mahesti, G., \& Koeswanti, H. D. (2021). Pengembangan Media Pembelajaran Permainan Monopoli Asean untuk Meningkatkan Hasil Belajar Tema 1 Selamatkan Makhluk Hidup Pada Siswa Kelas 6 Sekolah $\begin{array}{llll}\text { Dasar. Mimbar } & \text { PGSD }\end{array}$ https://doi.org/http://dx.doi.org/10.23887/jjpgsd.v9i1.33586.

McFeetors, P. J., \& Palfy, K. (2018). Educative experiences in a games context: Supporting emerging reasoning in elementary school mathematics. Journal of Mathematical Behavior, 50(May 2017), 103-125. https://doi.org/10.1016/j.jmathb.2018.02.003.

Nurfitriana, M. A., \& Nugraha, J. (2019). Pengembangan Permainan Monopoli Berbasis CAI Sebagai Media Pembelajaran pada Kompetensi Dasar Menganalisis Jabatan, Tugas dan Uraian Pekerjaan Kelas X MP 1 SMKN 2 Duduran Sidoarjo. Jurnal Pendidikan Administrasi Perkantoran, 07(4), 51-58.

Nurjanah, S., \& Sumarmi. (2020). Pengembangan Media Pembelajaran Teka-Teki Silang (Tts) Pada Pembelajaran Tematik Tema Cita-Citaku Kelas Iv Di Mi Al Busyro. PREMIERE : Journal of Islamic Elementary Education, 2(1), 31-42. https://doi.org/10.51675/jp.v2i1.85.

Peranti, P., Purwanto, A., \& Risdianto, E. (2019). Pengembangan Media Pembelajaran Permainan Mofin (Monopoli Fisika Sains) Pada Siswa Sma Kelas X. Jurnal Kumparan Fisika, 2(1), 41-48. https://doi.org/10.33369/jkf.2.1.41-48.

Pradana, M. R. S. (2018). Pengembangan Media Monopoli Tema Indahnya Keberagaman untuk Meningkatkan Hasil Belajar Siswa Kelas IV di SD 1 Patalan. 7(5), 500-511.

Prayogo, B. adi, Trimurtini, \& Sukarjo. (2017). Permainan Monopoli Sebagai Media pembelajaran Matematika. 6(4), 228-234.

Putra, I. G. A. S., \& Putra, D. K. N. S. (2021). Komik Pendidikan Berorientasi Children Learning in Science Pada Muatan IPA di Sekolah Dasar. Jurnal Pedagogi Dan Pembelajaran, 4(1), 81-89. https://doi.org/http://dx.doi.org/10.23887/jp2.v4i1.32434.

Rasvani, N. L. A., \& Wulandari, I. G. A. (2021). Pengembangan Media Pembelajaran Aplikasi MaCa ( Materi Pecahan ) Berorientasi Teori Belajar Ausubel Muatan Matematika. Mimbar PGSD Undiksha, 9(1), 74-81. https://doi.org/http://dx.doi.org/10.23887/jjpgsd.v9i1.32032.

Ruipérez-Valiente, J. A., \& Kim, Y. J. (2020). Effects of solo vs. collaborative play in a digital learning game on geometry: Results from a K12 experiment. Computers and Education, 159(August). https://doi.org/10.1016/j.compedu.2020.104008.

Sakiyah, E., \& Sunarti, V. (2020). The Relationship Between Learning Strategy for Office Aplication With Learning Succes at LKP Widyaloka Bukittinggi. SPEKTRUM: Jurnal Pendidikan Luar Sekolah (PLS), 8(4), 477. https://doi.org/10.24036/spektrumpls.v8i4.110086.

Sentarik, K., \& Kusmariyatni, N. (2020). Media Pop-Up Book pada Topik Sistem Tata Surya Kelas VI Sekolah Dasar. Jurnal Ilmiah Sekolah Dasar, 4(2), 197. https://doi.org/10.23887/jisd.v4i2.25135.

Septiani, N. W. W., \& Astawan, I. G. (2020). Pengaruh Model Pembelajaran TPS Berbasis Lingkungan Terhadap Sikap Peduli Lingkungan Dan Kompetensi IPA. International Journal of Elementary Education, 4(1), 44. https://doi.org/10.23887/ijee.v4i1.24332.

Suryani, N., Setiawan, A., \& Putria, A. (2018). Media Pembelajaran Inovatif dan Pengembangannya. PT Remaja Rosdakarya.

Trianawati, I. G. A. K., Ardana, I. K., \& Abadi, I. B. G. S. (2020). Pengaruh Model Discovery Learning Berbantuan Media Audio Visual Terhadap Kompetensi Pengetahuan IPA. International Journal of Elementary Education, 4(3), 398. https://doi.org/10.23887/jppp.v4i3.27428.

Ulfa, K., \& Rozalina, L. (2019). Pengembangan Media Pembelajaran Monopoli Pada Materi Sistem 
Pencernaan Di Smp. Bioilmi: Jurnal Pendidikan, 5(1), 10-22. https://doi.org/10.19109/bioilmi.v5i1.3753.

Utami, I. K., \& Abdulah, M. H. (2020). Pengembangan Media Ular Tangga dalam Pembelajaran Tema Daerah Tempat Tinggalku Peserta Didik Kelas IV Sekolah Dasar. Jurnal Pendidikan Guru Sekolah Dasar, 8(3), 581-590.

Viana Sari, D., \& Kusmariyatni, N. (2020). The Validity of the Pop-Up Book Media on Puberty Topics for Sixth Grade Elementary School. International Journal of Elementary Education, 4(2), 179. https://doi.org/10.23887/ijee.v4i2.25295. 